\title{
Die Apostoliese tradisie in die Vroeë Kerk se verstaan van Skrif en geloof -'n Kort hermeneutiese oorsig
}

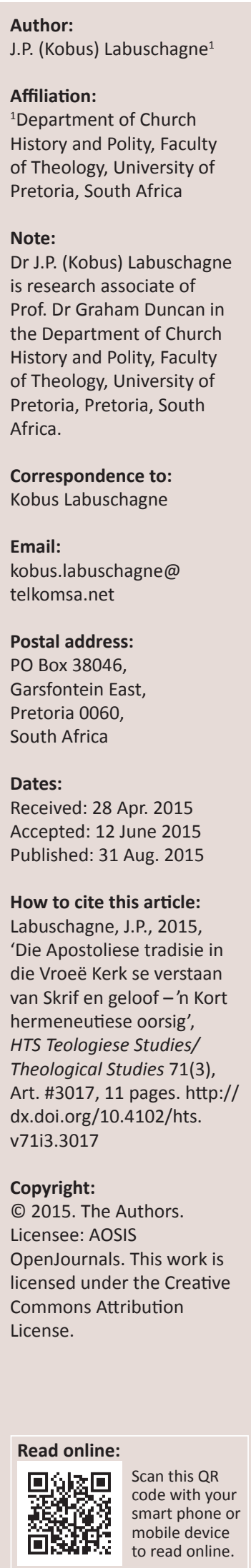

The Apostolic tradition in the Early Church's understanding of Scripture and faith - A brief hermeneutical overview. This study is a concise hermeneutical overview of faith's various ways of understanding and of the different approaches towards Scripture interpretation in the history of the Early Church. The research manifests that historically the Apostolic Tradition of the Early Church, with its ecumenically accepted expression of faith in the Nicene Confession (originating from the Ecumenical Councils of Nicaea 325 and Constantinople 381), offers a foundation towards Church unity and at the same time provides us with a vital hermeneutical key for the Church's understanding of the scriptures and of her faith.

\section{Inleiding}

Die verstaanprosesse in die kerk se geskiedenis moet iewers heen op pad wees. Die uitdaging en onderneming van hierdie studie is om aan te toon dat die hermeneutiese proses in die kerk se geskiedenis sinvol op pad is vanuit sy agtergrond in die Here Jesus Christus self en vandaar vanuit die agtergrond in die Apostoliese tradisie. Vanuit hierdie tradisie bely die kerk deur die eeue en oor die wêreld heen, soos verwoord in die Niceense Geloofsbelydenis (325 en 381), geloof in die Drie-enige God, en getrou aan God wat mens geword het, word daarmee saam gebondenheid bely aan sy kerk, as: Een heilige Algemene (Katolieke) en Apostoliese Kerk (vgl. Young 2007:5). Hierdie studie wil veral let op die hermeneutiese implikasies van wat dit behels om te praat van die Apostoliese Kerk, die kerk wat in hierdie tradisie, vanaf die apostels van die Here Jesus Christus voortgang gehad het en steeds het.

Die studie is beperk tot 'n bondige hermeneutiese ondersoek oor hoe daar, op verskillende maniere en gedurende verskillende periodes in die Vroeë Kerk se geskiedenis, in relasie tot die Apostoliese tradisie, oor geloof gedink is en tot verstaan gekom is van die Bybel se boodskap. Deurgaans bly dit belangrik vir die ondersoek om nie vasgevang te word binne 'n kokon van 'n spesifieke eietydse model van denke nie, en om dan daarvolgens bloot die eietydse beskouings in te lees in die verlede, en die verlede gemaklik te onderskat met geykte terme soos pre-modern en pre-wetenskaplik. Die uitdaging bly, inteendeel en uitdruklik, om ontvanklik te wees vir die denke en wêreld van die verlede, en dit 'n geleentheid te bied tot spreke en bekendstelling. Met nugtere openheid word geleentheid gebied aan die verstaanswêreld van verskillende tye en omgewings, van gister en vandag, om by mekaar uit te kom. Dit alles behels 'n ingesteldheid om uit die groter geheel van verskillende insigte by leidende denke deur die eeue, en die resultaat van daardie invloede in die kerk, tot nuwe helderheid te kom van ons eie soeke en nadenke.

Die hermeneutiek het te doen met'n verantwoordbare, dit wil sê, wetenskaplik-geleide analisering en interpretasie van tekste en dokumente uit die verlede. So gesien, het ons ondersoek na die interpretasie van geloof en die Skrif nie bloot te make met 'n oppervlakkige lees van tekste en ons onmiddellike respons daarop vanuit bevooroordeelde en ondeurdagte kontemporêre persepsies nie. Dis anders te sien: Die hermeneutiek het juis te doen met ' $n$ metodologie wat diensbaar is aan noukeurige ondersoek, verantwoordbare besinning en betroubare resultate. Die doel is om tot verstaan te probeer kom van wat 'n bepaalde teks of dokument sê, en inderdaad vir ons wil sê. Verder handel die hermeneutiek in sy gemoeidheid met wyses van interpretasie, juis oor mense van verskillende periodes se verstaan van waarheid en werklikheid. Daarmee staan die hermeneutiek voor geweldige uitdagings wat gestel word deur tallose inwerkende kontekste wat mense se verstaan affekteer. Om kontekste raak te sien, iets van te verstaan, kan nuwe insigte oopmaak in ons soeke na waarheid en werklikheid:

With words we express meaning and understanding. Words are, however, always related to a background or context. Then there is also the ripple effect created by multiple interdependent contexts to contend with. Context operates through both word and event. Context is the originating factor, resulting in our words through which we give meaning. Context cannot be downplayed, nor underestimated. (Labuschagne 2013:2 van 10) 
Paul Ricoeur (2009:166), in verwysing na wat hy noem 'contextual action', verduidelik dat ' $\mathrm{n}$ 'word is always the bearer of the "emergent meaning" which specific contexts confer upon $i t$ '. Relasie tot 'specific contexts' het ook 'n uitwerking op die interpretasie van metafore: '[T] he interpretation of local metaphors is illuminated by the interpretation of the text as a whole and by the clarification of the kind of world which the work projects' (Ricoeur 2009:180-181). Jürgen Moltmann (2000:166) waak teen eensydige vergeesteliking van begrippe en voeg dan by: ' $[A]$ metaphor begins to illuminate only if not everything is metaphorical'.

Fragmentering van tekste mag daartoe lei dat nie rekening gehou word met verbandhoudende kontekste nie en dat belangrike inligting gevolglik daarmee verlore gaan en die waarheid onderdruk word of selfs gekontamineer word. 'n Teks moet nie uit sy konteks of kontekste uitgelig word nie - tereg sê Jacques Derrida: '[T]here is nothing but context, and therefore: there is no outside-the-text' (Labuschagne 2013:2 van 10). Belangrik om in ag te neem, is dat daar konteks op konteks mag wees wat elkeen op 'n wyse bydra tot betekenis.

Die hermeneutiek se soeke na verstaan van waarheid en werklikheid kan in die realiteit van die ondersoek van tekste, dokumente en gebeure nie die vanselfsprekende van ontleding en uitmekaar haal-dekonstruksie-ontkom nie. Die postmoderne en poststrukturalistiese denke lewer 'n groot (en dikwels riskante) bydrae tot die hermeneutiese proses tot verstaan. Dit word riskant wanneer die ondersoeker se rol dit onmoontlik maak vir 'n teks om 'n duidelik aanduibare, of min of meer vaste betekenis, of een betekenis, te hê terwyl dit selfs moeilik gemaak word vir die teks om te sê wat die teks wil sê. Dekonstruksie is in hierdie opsig meer radikaal by Derrida as by Heidegger en Gadamer. John D. Caputo (1987) stel dit so:

Derrida is unquestionably the philosopher most faithful to the flux, most suspicious of every attempt to still its movements or, to use his own striking expression, to 'arrest the play.' There is a more Nietzschean side to Derrida than to Heidegger or Gadamer, a more deeply suspicious eye. (bl. 97)

Wat ondersoek word, kan egter nie onophoudelik suspisieus weerhou word van sy aanduiding van waarheid nie. Die hermeneutiese strewe is tog om iewers iets van die waarheid oop te maak en terug te vind. Tereg sê Caputo: 'There is no hermeneutic recovery without deconstruction and no deconstruction not aimed at recovery' (Caputo 1987:65).

Met die beste bedoelinge ten opsigte van tekste wat ondersoek word, moet die interpretasieproses bedag daarop wees dat tekste enersyds op overte wyse uitdrukking mag gee van hoe daar tot bepaalde verstaan gekom is, en dis dan makliker (die metodologie is opsigtelik), maar andersyds mag tekste ook weer op koverte wyse opereer en die metodologie van verstaan verskuil, en dan word dit veel meer ingewikkeld. Die navorser moet in elk geval daarteen waak om nie eie gedagtes in te lees in tekste nie. Menslike navorsing het nou eenmaal 'n subjektiewe element - die navorser volg 'n spoor, volg leidrade op; die navorser maak sy eie seleksie van ondersoekvelde, is verantwoordelik vir die metodologiese hantering van stof, en dit is uiteindelik die navorser se verhaal, of narratief dan. Geloofwaardigheid vra egter altyd verantwoordbaarheid. Hoewel ons menslike waarneming altyd 'interpretative perception' is, kan ons nogtans nie die geskiedenis 'invent' nie, om aan te sluit by die gedagtes van Frances Young. Sy verduidelik: 'History is largely "given": you cannot change the past, nor should you appropriate it in such a way that its "pastness" is compromised' (Young 2007:xiv). Kontekste moet voordurend toegelaat word om die tekste hulle ware inhoud te gee.

Hans-Georg Gadamer (1900-2002) identifiseer verstaan, en inderdaad kom tot verstaan, met effek in sy uiteensetting van hoe 'n bewussyn werk wat die effek ondergaan van die geskiedenis wat daarop inwerk. Hierdie bewussyn noem hy dan 'n wirkungsgeschichtliches Bewußtsein. Gadamer sê: 'Understanding proves to be a kind of effect and knows itself as such' (Gadamer 2006:336). Hy (Gadamer 2006) konstateer ook:

When a naïve faith in scientific method denies the existence of effective history, there can be an actual deformation of knowledge ... Consciousness of being affected by history (wirkungsgeschichtliches Bewußtsein) is primarily consciousness of the hermeneutical situation. (bl. 300-301)

Wat nou nodig word, is wat Gadamer (2006) noem 'n 'fusion of horizons':

$[U]$ nderstanding is certainly not concerned with ... reconstructing the way the text came into being. Rather, one intends to understand the text itself. But this means that the interpreter's own thoughts too have gone into re-awakening the text's meaning. In this the interpreter's own horizon is decisive, yet not as a personal standpoint that he maintains or enforces, but more as an opinion and a possibility that one brings into play and puts at risk, and that helps one truly to make one's own what the text says. I have described this above as a 'fusion of horizons'. (bl. 390)

Gadamer se kombinasie van verstaan en effek (effek wat die bewussyn tot verstaan gebring het) is egter op verskillende wyses nie iets nuuts in die Teologiegeskiedenis nie. Voorbeelde kan genoem word: Die verstaan van die Vroeë Kerk, Martin Kähler in die negentiende eeu, ook die Nederlandse Etiese Teologie in die negentiende eeu, en dan in die twintigste eeu die Dialektiese Teologie van onder andere Karl Barth en Emil Brunner.

\section{Die Vroeë Kerk en die Apostoliese tradisie}

In die waarheidsbegrip van die Vroeë Kerk, en in die verstaan van hulle geloof, het dit nie gegaan oor die rasionele abstrakte proposisies daargestel deur die neo-Platonistiese filosofie van hulle tyd nie, en dit het ook nie gegaan oor die persepsies van die gnostiek-beweging met hulle veronderstelde geheime kennis en verspiritualisering nie. Hierdie proposisies en veronderstellings was alles dinge waaroor die menslike bewussyn die indruk kon hê dat die mens self in beheer is oor die soeke na waarheid en werklikheid. Dit het vir die Vroeë Kerk nie gegaan oor 'n proposisionele waarheidsbegrip nie. 
Hulle waarheidsbegrip en die geloof wat hulle ervaar het en uiteindelik ook bely het in hulle Regula Fidei en Konfessies, het eerder gespreek van iets wat beheer oor hulle verkry het, van buite die mens, hulle wel persoonlik geraak en persoonlik gekonfronteer het, en uiteindelik hulle lewe totaal verander het. So gesien, is hulle konfessies dan uitdrukking van en heenwysing na 'n lewende geloofsontmoeting wat plaasgevind het, en daarvandaan wys die ontmoeting na die oorsprong daarvan in die Christus-gebeure wat in ons wêreldgeskiedenis manifesteer word. Ignatius Biskop van Antiochië (35-107) praat in sy 'Brief aan die Efesiërs' van geloofsontmoeting in terme van die Christen se persoonlike geloof en liefde teenoor die Here Jesus Christus:

... I intend to write to you ... about ... the divine plan with respect to the new man Jesus Christ, involving faith in him and love for him, his suffering and resurrection, especially if the Lord reveals anything to me. (Ignatius 2009a:199)

In sy 'Brief aan die Magnesiane' sê Ignatius (2009b) van hierdie geloofsverhouding:

$[I] \mathrm{n}$ order that we may be found to be disciples of Jesus Christ, our only teacher, how can we possibly live without him. (bl. 209)

Die Vroeë Kerk lewe in 'n lewende verhouding met die Here Jesus Christus, in die presensie van die Here. Sodanig was hulle geloof dat talle van hulle selfs bereid was om die wreedste marteldood, onder die ergste boosaards van die wêreld, vir die Here Jesus Christus te verduur. Die martelare was sulke ongelooflike mense, dapper en edel en getrou - ' $[d]$ ie wêreld was hulle nie werd nie' (Heb 11:38). Hulle sal altyd deur die kerk onthou word, hulle vir wie die lewe alleen sin kon hê saam met die Here Jesus Christus en naby Hom. So was dit die geval ook met Polycarpus Biskop van Smirna (ca. 69-155), wat geleer het by die apostels, en in die presensie van Christus lewe (Irenaeus 2010:280), en geweier het om die Here Jesus te verwerp voor prokonsul Statius Quadratus. Polycarpus bely so sy verbintenis aan die Here Jesus Christus deur heel sy lewe, voor hy die marteldood sterwe:

For eighty-six years I have been his servant, and he has done me no wrong. How can I blaspheme my King who saved me? (Letter of the Church of God at Smyrna to the Church of God at Philomelium 2009:317)

In Matteus 16:16 kom Petrus se geloof in die Here Jesus tot uitdrukking in die belydenis: ' $U$ is die Christus, die Seun van die lewende God'. Hiervan sê Bernhard Lohse (1985):

Since this confession by Peter there has never been a time when Christians did not face the task of expressing their faith in the form of a confession ... The first and most important reason for fuller elaboration of confession, as well as for the development of doctrine, at least at the beginning, is the fact that very soon after the crucifixion and resurrection of Jesus the primitive community began to pray to its exalted Lord ... Prayers can be addressed only to God. If they are addressed to Jesus Christ, therefore, the question concerning the relationship of the exalted Lord to God necessarily arises. Hence the development of the dogma of the Trinity and of the Christology has its beginnings in the early days of the church, even though it took a long time before a doctrine was actually formulated. (bl. 9)
Hoewel omstandighede in die Vroeë Kerk die kerkvaders gelei het tot groeiende nadenke oor leerstellige aangeleenthede en die resultate van hulle denke uiteindelik in die kerklike konfessies uitmond, en die dringendheid van elke periode die agenda bepaal het in die volgorde van Godsleer, Triniteit, Christologie, verlossingsleer en sakramentsleer, was alle ontwikkelings van die begin af nou verweef met die mens se verlossing in Christus. Vir die Vroeë Kerk was die verlossingsleer, en dit is baie belangrik om raak te sien, gekoppel aan die skeppingsleer in terme van God se herskepping en voortgaande skepping (vgl. Moltmann 2010:202-206; Young 2007:xv, 2010a:57). In sy sterwensuur bely Polycarpus Christus as 'my King who saved me' (Letter of the Church of God at Smyrna to the Church of God at Philomelium 2009:317). Die verlossing van die mens in Christus, was inderdaad in baie opsigte die eintlike dryfveer in die leerstellige ontwikkeling:

For in fact the controversies which produced the doctrines which reached formal definition were often fired by concern that the gospel of salvation be safeguarded ... Like the Bible, doctrines served the purpose of articulating the saving Word. (Young 2007:82)

Vir die Vroeë Kerk het dit nie gegaan om bloot woorde op sigself nie; die woorde het gewys na iets. Woorde (soos in hulle Konfessies) het uitdrukking gegee van hulle opregte geloof, en die waarheid agter daardie geloof. Die waarheid is dus nie bloot geleë in proposisies en stellings van die menslike bewussyn nie, maar dit gaan om die werklikheid daaragter. So sal Irenaeus byvoorbeeld sy Regula Fidei in verskillende weergawes aanbied en op verskillende wyses verwoord, maar waarvan die strekking uiteindelik altyd dieselfde inhoud gedien het (Young 2007:9). Wat hulle bely (in hulle Regula Fidei en in hulle Konfessies wat in die essentialia daarvan nie van mekaar verskil het nie), is so dan, uitdrukking van hulle geloof en nie die grond van hulle geloof nie. Duidelik het ons hier dus nie te doen met 'n proposionele waarheidsbegrip (of 'n verobjektiveerde waarheidsbegrip) nie - iets wat wel later in die Teologiegeskiedenis meermale sou voorkom. Dit gaan oor geloof, met 'n werklikheid daaragter.

Wat die Vroeë Kerk bely, is 'n poging om in menslike taal iets te probeer sê van geloof, van 'n persoonlike geloofsontmoeting met die lewende God, maar meer nog, wat Hom sigbaar gemaak het en Hom openbaar het in die persoon en werk van ons Here Jesus Christus in die menslike geskiedenis. Die presensie van Christus kom sterk na vore, sodat, byvoorbeeld, Ignatius (2009c:35-107), biskop van Antiochië en leerling van Johannes (die apostel), sê in sy 'Brief aan die Smirniote' (en die eerste was om dit te sê) dat die algemene Kerk daar is waar Christus teenwoordig is:

Wherever the bishop appears, there let the congregation be; just as wherever Jesus Christ is, there is the catholic church. (bl. 255)

God is your reward; if you endure everything for his sake, you will reach him. (bl. 257)

May my spirit be a ransom on your behalf, and my chains as well, which you did not despise, nor were you ashamed of them. Nor will the perfect hope, Jesus Christ, be ashamed of you. (bl. 257) 
Die Vroeë Kerk wou die waarheid wat tot hulle gekom het in Christus (in die presensie van die Here Jesus Christus in sy Gees) elke dag gehoorsaam, gelowig dien en dit dan getrou uitdra aan die wêreld daarbuite. Daar is dus 'n voortgaande en lewende verhouding, met sy oorsprong in ' $n$ bepaalde openbaringsgebeure van God - juis die gebeure waarna die Regula Fidei en die Konfessies verwys, waarvan berig word in die Bybel, waarvan die Bybel se boodskap getuig, en wat ook deur die kerk verkondig word. Die getuienis, die beriggewing, die voortgaande verkondiging bring ons by die Apostoliese tradisie. Die Apostoliese tradisie was daarop ingestel om die waarheid wat van die apostels ontvang is, te bewaar en getrou oor te dra van geslag tot geslag (vgl. Labuschagne 2013:6-7 van 10). Die Vroeë Kerk se ingesteldheid op die waarheid kan as ortodoks beskrywe word, maar dan nie ortodoks in die moderne sin van 'n proposionele waarheidsbegrip (onder die dwang van selfstandige leerstellige definisies) nie, maar in die sin van Frances Young se beskrywing daarvan as 'concern about truth, about the ways things really are' (Young 2007:15). Ortodoks sou dan ook wel in hierdie sin van bewaring van die waarheid ' $n$ beperkte toleransie vir afwykende sienings handhaaf.

Die Apostoliese tradisie van die Vroeë Kerk het totaal verskil van die beskouings van die neo-Platonisme en die gnostiek. Die Apostoliese tradisie het die Platonistiese dualisme van 'n skeiding tussen letterlike en simboliese betekenis (tussen geestelike en liggaamlike of materiële) oorwin, en die skeiding opgehef (Young 2007:xv). Standvastig in die Apostoliese tradisie, het die Vroeë Kerk die eenheid van liggaam en gees gehandhaaf. As deel van hierdie tradisie, het die Vroeë Kerk hulle taak gevind.

Irenaeus (ca. 130-200) bring die Apostoliese tradisie van die Vroeë Kerk in perspektief - en dan ook in die konneksie daarvan met apostoliese suksessie. In terme van apostoliese suksessie is die opeenvolgende gesag en verantwoordelikheid van die biskoppe gefokus op een groot en belangrike missie: Die oordra van die waarheid wat in en deur die Here Jesus Christus gekom het, en waarvan die Bybel berig gee (vgl. Irenaeus 2010:278-280). Die waarheid moes beskerm word teen afwykende en verkeerde beskouings. Dit was vir hulle daarom belangrik dat 'n lyn van opeenvolgende biskoppe aangetoon moes kon word in die oordra van die waarheid so moes geverifieer word dat die boodskap oor die waarheid duidelik teruggaan tot by die apostels en, deur hulle, tot by die Here Jesus self. Vir niks anders moes ruimte gelaat word nie.

Irenaeus was die biskop van Lyons, en sy lyn van suksessie en die oordra van die waarheid kon teruggevoer word na Polycarpus (ca. 69-155), biskop van Smirna, en deur Polycarpus na die apostels (Irenaeus 2010:280). Irenaeus (2010) verduidelik self sy konneksies via Polycarpus, 'whom I also saw in my early youth':

But Polycarp also was not only instructed by apostles, and conversed with many who had seen Christ ... gloriously and most nobly suffering martyrdom, departed this life, having always taught the things which he had learned from the apostles, and which the Church has handed down, and which alone are true. (bl. 280)
Die Apostoliese tradisie en apostoliese suksessie van die Vroeë Kerk het geen konneksie gehad met die aansprake van die latere kerklike magspolitiek van die biskoppehiërargie nie. Dit gaan oor die waarheid wat gehandhaaf moes word teen verkeerde beskouings, in eenheid van geloof en in die een kerk. Irenaeus (2010) sê:

[T] he apostolic tradition has been preserved continuously by those [faithful men] who exist everywhere. (bl. 279)

$[A]$ nd we are in a position to reckon up those who were by the apostles instituted bishops of the Churches, and [to demonstrate] the succession of these men to our own times; those who neither taught nor knew of anything like what these [heretics] rave about. (bl. 278)

$[A]$ nd by this succession, the ecclesiastical tradition from the apostles, and the preaching of the truth, have come down to us. And this is most abundant proof that there is one and the same vivifying faith, which has been preserved in the Church from the apostles until now, and handed down in truth. (bl. 280)

Behalwe die Niceense Geloofbelydenis (325 n.C. \& 381 n.C.) se bekende verwysing na die Apostoliese Kerk (vgl. Young 2007:5), gaan die Konfessie van Chalcedon (451 n.C.) breër in op die volgehoue oordra van die waarheid, en verwoord dan in relasie tot die Here Jesus Christus so:

[J]ust as the prophets taught from the beginning about him, and as the Lord Jesus Christ himself instructed us, and as the creed of the fathers handed it down to us. (Drobner 2007:488)

A. van de Beek (2012) verwys na Irenaeus en Tertullianus vir die verstaan van apostoliese suksessie, beklemtoon leer, lewe en amp, en vat dit so saam:

Het ambt is vanaf het begin van de kerk een essentiële factor van haar identiteit geweest. Zonder mensen aan wie de verantwoordelijkheid voor de kerk is toevertrouwd, kan zij niet goed functioneren. Er is een instantie nodig die de kerk bewaart bij Christus en haar geloof en leven in rechte paden voert. In eerste instantie zijn dat de apostelen die Jesus hebben gezien en getuigen zijn van zijn opstanding. Hun taak is overgedragen aan bisschoppen en presbyters, met de diakenen als helpers. $\mathrm{Zij}$ moeten de gemeente bewaren wanneer ketters als wolven binnenkomen en allerlei morele gevaren de kerk bedreigen. $\mathrm{Zij}$ moeten zorgen dat de lijn die door de apostelen in opdracht van Christus is uitgezet, wordt bewaard en dat ook een nieuwe generatie die vasthoudt.

Zo komt men welhaast als vanzelf bij het begrip apostolische successie. (bl. 261)

Die Nuwe Testament en die Vroeë Kerk staan in 'n unieke en baie noue verbondenheid met mekaar. Die Nuwe Testament en die Vroeë Kerk is in albei gevalle, tot 'n baie hoë mate, uitdruklik die een die ander se verduidelikende konteks. Ons verstaan die een daarom beter uit die konteks van die ander. Dit kan hermeneuties alleen rampspoedige gevolge hê, indien dit nie telkens raakgesien word nie (afgesien van die rol van bykomende kontekste in verskillende situasies). Die twee saam vorm vervolgens, op verskillende wyses in verskillende situasie, telkens agtergrond en verklarende konteks vir die voortgaande verstaanprosesse van die geheel van die kerk se geskiedenis. 


\section{Nadere beskouing van geloof en aspekte van Skrifinterpretasie in die Apostoliese tradisie en in die geskiedenis van die Vroeë Kerk: 100-600}

Belangrik vir die ondersoek na die wyse van interpretasie van geloof en die Skrif by die Vroeë Kerk was dat hulle hermeneutiese verstaan sy laaste grond vind buite die menslike bewussyn - afgesien van die belangrikheid wat die ontmoetingsgebeure in die gemoed van die mens het. Karl Barth (1886-1968) beskrywe dit (in aansluiting by 1 Joh 1) met indringende begrip wanneer hy verwys na die belewing en respons van die Vroeë Kerk op die gebeure (Ereignisse) van Christus se opstanding en hemelvaart - 'mit Augen gesehen, mit Ohren gehört, mit den Händen betastet wird' (Barth 1955:160):

$[A] n$ event within the world, in time and space. ... It, too, was experienced and attested, not only inwardly but outwardly, by certain men. ... It is an event which involves a definite seeing with the eyes and hearing with the ears and handling with the hands ... then believing ... and later attested by them. (Barth 2000:143)

Uiteindelik is daar nou ses belangrike hermeneutiese rigtinggewers (vgl. Confessing the One Faith 2010:76-78, 100) wat onderskei moet word in die oorkoepelende Apostoliese tradisie (voordat na verdere detail in relasie tot hierdie tradisie gekyk kan word):

1. Hulle geloofservaring (en die geloofsontmoeting wat daarmee in verband staan) het sy agtergrond in daardie waarheid wat van die apostels ontvang is en wat getrou van geslag tot geslag oorgedra moet word (na die betekenis van die Latynse woord trado, en waarvan die woord 'tradisie' afkomstig is).

2. Die waarheid wat hulle ontvang het, verwys na die werklikheid van gebeure rondom die persoon en werk van die Here Jesus Christus, en wat die apostels en hulle assosiate met hulle oë gesien het, met hulle ore gehoor het, met die hande daaraan gevat het, en dit aan die wêreld vertel het.

3. Die geloof van die Vroeë Kerk reageer op God se soewereine magsingryp in hierdie wêreld, dit volg op God se selfopenbaring in Jesus Christus, die Here, en dit is nie die produk van gewone menslike redenasies en spekulasie as verlengstuk (of projeksie) van menslike strewe en verlange nie, dis nie die produk van menslik rasionele immanentisme nie.

4. Die getuienis van die apostels, oor die kruis en opstanding van die Here Jesus Christus, (afgesien van die aanvanklike mondelinge tradisie) word in die Bybel berig en deur die Heilige Gees in die harte van gelowiges bevestig.

5. Die waarheid wat bely word in die Regula Fidei en Ekumeniese Konfessies van die Vroeë Kerk, is uitdrukking van hulle geloof en nie die grond van hulle geloof nie.

6. Vir die Vroeë Kerk was die gebeure rondom die Here Jesus, veral sy kruis en opstanding, so oorweldigend en buitengewoon dat dit vir hulle baie moeilik te verstaan was. Hulle soek gevolglik voortaan hulle antwoorde op twee maniere: (a) In hulle Joodse agtergrond in die Ou Testament, sodat die Ou Testament nou vir hulle sin verkry in Jesus Christus, en dan interpreteer hulle die Ou Testament so. (b) Om hierdie boodskap te kon kommunikeer aan hulle wêreld, word nou ook van Griekse begrippe uit die Griekse filosofiese wêreld gebruik gemaak, en aan daardie begrippe word wel nou nuwe inhoud verleen, om die boodskap te kon oordra (soos byvoorbeeld die logos-begrip in Johannes 1 - wat vertel dat die Woord mens geword het anders as dit wat die neo-Platonisme sou verwag).

As voorbeeld, verwys Frances Young (2007) na Justinus die Martelaar:

Justin saw Christianity as the fulfilment not only of Judaism, but of all philosophy. Philosophy provided him and other apologists with the language and conceptual tools to explain how Jesus Christ was the revelation of the one true God. (bl. 35)

Afgesien van die oorkoepelende Apostoliese tradisie wat tot uitdrukking kom in die Vroeë Kerk se belydenis in byvoorbeeld die verskillende (en tog ooreenstemmende) Regula Fidei (deur Irenaeus, Tertullianus en Origenes, met ook reeds veel vroeër ' $n$ ooreenstemmende belydenis deur Ignatius) en in byvoorbeeld die latere Ekumeniese Konfessies (soos by Nicea-Konstantinopel [325 en 381] en Chalcedon [451]), was daar aansluitend daarby tog verdere aspekte rakende geloof en Skrifinterpretasie wat in die teologiese debatte na vore gekom het en 'n rol gespeel het. Enkele voorbeelde verdien aandag.

\section{Interpretasie in die periode van die apostels: $\mathbf{3 0 - 1 0 0}$}

In die kerk se geskiedenis het die oorgang van die Joodse na die vroeë Christelike interpretasie van geloof en die Skrif 'n tweeledigheid gehad: kontinuïteit en diskontinuïteit. Enersyds is die Joodse verstaan tot 'n bepaalde mate gehandhaaf, maar in hoofsaak was daar 'n nuwe benadering. Die skerp verskil wat die apostels en die Vroeë Kerk bring, was om die Here Jesus te sien as die letterlike vervulling van die Ou Testamentiese profesie. In hoofsaak word die hele $\mathrm{Ou}$ Testament nou geïnterpreteer vanuit die persoon en werk van die Here Jesus Christus. Hieronder kan verskillende benaderings onderskei word, soos: Toepassings van $\mathrm{Ou}$ Testamentiese beginsels (byvoorbeeld dat God nie net die Jode geroep het nie, maar ook die nasies), tipologiese interpretasies en kontekstueel letterlike interpretasies (vgl. Labuschagne 2001:968).

\section{Interpretasie in die periode van die apostoliese vaders: $\mathbf{1 0 0 - 1 5 0}$}

In hierdie tyd word die tipologiese metode soms aangewend om die Ou en Nuwe Testament met mekaar te verbind. Die allegoriese metode is egter die meer populêre metode van interpretasie, en hiervolgens word in elke detail van 'n teks 
gesoek na 'n verskuilde geestelike (simboliese) betekenis. As voorbeeld kan verwys word na die Brief van Barnabas wat die ses skeppingsdae simbolies geïnterpreteer het om te sê dat die wêreld sesduisend jaar sal bestaan, en die sewende dag simboliseer dan die wederkoms van die Here Jesus (vgl. Labuschagne 2001:969). Die verskil wat hierdie soort vergeesteliking van die teks gehad het met die simboliese verklarings wat sedert die negentiende eeu na vore tree, was dat daar in die Vroeë Kerk gereik is na die goddelike (die menslike is selfs verloor in die geestelike wêreld van God), terwyl in die negentiende eeu en daarna weer gepoog word om alles te vermenslik en te veraards (sodat selfs die goddelike dimensie verloor word in die menslike verstaan en belewing).

\section{Interpretasie in die periode van Alexandrië versus Antiochië: 150-400}

Na die periode van die apostoliese vaders het die Christelike geleerdheid sentreer rondom die twee skole van Alexandrië en Antiochië - met elk hulle eie voorkeure, onder andere in Skrifinterpretasie (vgl. Labuschagne 2001:969-971). Albei deel nietemin, dieselfde basiese Christelike geloof soos dit tot uitdrukking kom in die Apostoliese tradisie - wat onder andere verwoord word in die Regula Fidei van die kerkvadere en daaropvolgende Ekumeniese Konfessies van daardie tyd.

Die Skool van Alexandrië het tot 'n beduidende mate die allegoriese interpretasie gevolg, in 'n tyd toe Alexandrië lankal reeds hierdie metode onder Jode en neo-Platonistiese filosowe geken het. Met hierdie metode het Christelike geleerdes gehoop om groter aanvaarding onder nieChristene te verkry. Clemens van Alexandrië (ca. 150-215) het onder neo-Platonistiese invloed geleer dat die Skrif tweeledig geïnterpreteer moet word: $\mathrm{Na}$ analogie van die mens as liggaam en siel moet die Skrif letterlik en figuurlik (laasgenoemde sê allegories) verklaar word en die geestelike betekenis is as die belangrikste beskou. Origenes (185-254) volg Clemens op en, in navolging van die neo-Platonistiese invloed, voer hy die allegoriese metode verder. Dit beteken egter nie dat hy breek met die Apostoliese tradisie nie; sy Regula Fidei bevestig sy trou aan die Apostoliese tradisie (Young 2007:10, 11). Young toon aan dat Origenes se hantering van allegorie nie so eenvoudig was nie, en dit verwys na 'n groter kompleksiteit as wat oorvereenvoudigde negentiende en twintigste eeu se afleidings meermale maak:

Origen's treatment of the Bible bears comparison with Neoplatonic treatment of Homer. Yet he also had some contact with Jewish scholarship, and was less keen than Clement to adopt the language of mysteries, Gnostics and theosophists. His use of allegory is rooted in inherited church traditions. (Young 2002:292)

Die kritiek was dat Origenes in sy subjektiewe (allegoriese) hermeneutiek sy eie siening in die Skrif ingelees het. Groot weerstand onder kerkleiers van die Vroeë Kerk volg (vgl.
Labuschagne 2001:971). Young (2002) wys op die rolspelers in die stryd teen allegorie:

The fourth-century Origenist controversy directly involved not just the Westerners Jerome and Rufinus, but also Epiphanius and, fatefully, John Chrysostom in the East. It came somewhat later than the attacks on allegory from Eustathius, Diodore and Theodore. We should not, however, underestimate the doctrinal dimensions of the Antiochene reaction against allegorical readings, and it must be recognised that, in the period of Arian and post-Arian conflict, Origen's 'playing' with the text became less and less viable. (bl. 296)

Kritici stig uiteindelik 'n tweede skool in Antiochië, in Sirië (in die vierde eeu).

Die Skool van Antiochië (wat Joodse invloed vertoon) het, teenoor 'n bloot allegoriese uitleg, 'n meer histories grammatiese (of realisties-grammatiese) verstaan van die Skrif geleer, om tot 'n beter verstaan van tekste te kom. Die letterlike betekenis was vir Antiochië belangrik. Uit die verstaan van eerstens die letterlike betekenis (van werklike fisiese gebeure) wou hulle uitkom by die geestelike- of geloofsverstaan. Dit was vir Antiochië belangrik om die verband tussen werklike gebeure en geestelike betekenis raak te sien. Theodorus van Mopsuestia (ca. 350-428) is 'n groot leidende figuur in Antiochie in hierdie tyd. Hy het byvoorbeeld die lank aanvaarde allegoriese (vergeestelikte) verklaring van Hooglied verwerp (naamlik van Christus se liefde vir sy kerk), en geleer dat Hooglied 'n liefdesgedig is wat verwys na Salomo se huwelik met 'n Egiptiese prinses. Veral Chrysostomos (ca. 347-407) het die metode van Antiochië baie goed weergegee. Sy uitgebreide geskrewe werk word soms met dié van Augustinus (354-430) vergelyk. Hy was sy tyd voor wanneer hy van die mensheid en Godheid in die een persoon van Christus tegelyk eenheid en ongemengdheid leer (Labuschagne 2001:971; Young 2002:296). Tog was die hantering van die allegorie nie volledig beperk tot die Weste nie; Young (2002) wys op die volgende:

[I] t was a case not just of literal reading ... Traditional types and allegories went unquestioned, as did the Christological reference of the Old Testament ... But the stories and language of the Bible increasingly functioned to produce for society a new culture ... And allegory remained the principle way of probing beneath the wording of scripture to its theological reference and deeper spiritual sense in the exegetical traditions of East and West. (bl. 298-299)

\section{Interpretasie in die periode van die Ekumeniese Konsilies - circa 325-600}

Na die bekering van die Romeinse keiser, Konstantyn, in 312 n.C., het politiek ' $n$ hermeneutiese faktor begin word, waarop kerk en teologie voortaan bedag sou moes wees, want eenstemmigheid in die kerklike leer kon in hierdie tyd 'n bydrae lewer om politieke stabiliteit in die Romeinse Ryk te bevorder. Gevolglik is daar nou polities druk uitgeoefen met die oog daarop dat die ortodokse hoofstroom in die kerk en die afwykende groepe mekaar 
vind (vgl. Labuschagne 2001:971). Daarmee het in die geskiedenis, openlik of verskuil, politieke (en ideologiese) druk op die kerk en teologiese denke gekom om te bly. Daar moet egter gewaak word teen oorvereenvoudigings om te veel te wil maak van politieke invloed en dan, meer spesifiek, Konstantyn se rol in die kerk se teologiese ontwikkeling, want dit is veel meer kompleks (vgl. Young 2010b:64-75). Die historiese navorser mag hier (en ook in talle ander kritiese situasies wat nog sou kom) nie swig voor aanleidings om in ' $n$ tonnelvisie te verval nie en net een of partikuliere tendense raak te sien nie. Daar moet verder ook gewaak word teen die sogenaamde blame game met sy eie obskure agenda en voortspruitende ingesteldheid to rewrite history. Talle uitkringende kontekste wat die voortgang van die kerk en die teologiese debat raak, mag eenvoudig nie geïgnoreer word nie. Die Vroeë Kerk se komplekse situasie van talle verbandhoudende kontekste, soos die Joodse agtergrond; die voortgaande invloed van die neo-Platonistiese filosofie en daarteenoor die Apostoliese tradisie; die rigtinggewende bydraes van die kerkvadere; die Regula Fidei en ander streekskonfessies; die rol van afwykende beskouings in die debatte en voortspruitende optredes van die kerkvadere en die Vroeë Kerk in hierdie verband; voortdurende nuwe kwessies en vrae waarop antwoorde gesoek moet word; die verskillende interpretasies van die skole van Alexandrië en Antiochië; die Ekumeniese Konsilies van die Vroeë Kerk wat moontlik geword het nadat die Romeinse owerheid nie meer die Kerk bedreig en vervolg het nie - dit alles en selfs meer kontekste moet ondersoek word vir die waarheid van die volle werklikheid. Om die politiek, of watter ander faktor nou ook al, uit te sonder, sal nie die oorweldigende magdom van ander faktore wat soos die wye oseaan se groot golwe op golwe, wat oor eeue heen gekom het, bloot kan laat verdwyn nie. Die geskiedenis moet toegelaat word om self sy verhaal voor te hou, in sy verskeidenheid van verbande en kontekste, en sonder manipulasie van inhoude.

Die Vroeë Kerk het sy agtergrond gehad in die Judaïstiese monoteïsme - God is een. Tog het hulle ook vanaf die begin reeds Jesus bely as God. Bernhard Lohse wys alreeds na aanduidings van die preëksistensie van Christus en die predikaat 'God' wat aan Christus toegevoeg is, in die Nuwe Testament (Lohse 1985:38, 39). Selfs die Romeinse owerheid word vroeg reeds bewus daarvan dat die Christene vir Jesus bely as 'God', soos blyk uit 'n lang verslag van Plinius, goewerneur van Bitinië (ca. 112 n.C.), aan keiser Trajanus (Barnett 1998:27). Christoph Schwöbel (2009:25-37) wys op, wat hy noem, 'a prototrinitarian grammar of Christian discourse on God' in beide Ou en Nuwe Testament. Die Vroeë Kerk se verstaan van God het in groeiende mate onder druk begin kom vir groter duidelikheid, vir die kerk self, vir die kerk se boodskap aan 'n Griekse denkwêreld, maar ook in die lig van talle afwykende beskouings (soos dié van die gnostiek en die Arianisme) waarop die kerk moes reageer. Die geloof self het groter klaarheid gevra:

[I]t can hardly be doubted that the affirmations of faith which the first Christians made with reference to God the Father, Son, and Holy Spirit, and which were based upon God's act in Jesus
Christ and upon the pouring out of the Holy Spirit, simply cried out for fuller elaboration ... The faith itself demanded greater clarity. (Lohse 1985:40, 41)

From the beginning, of course, certain fundamentals were firmly held by the church, namely, that God is one, i.e., that it did not believe in two, let alone three gods; that this one God has revealed himself in a threefold way as Father, Son, and Holy Spirit; that Father and Son may not be equated in a way which dissolves the differences between them ... (Lohse 1985:41)

Die Ekumeniese Konsilies van die Vroeë Kerk het in hulle konfessies die noodsaaklike groter duidelikheid gebring ten opsigte van die geloof wat die kerk bely het - veral ten opsigte van die Godsleer (Triniteit) en Christologie wat in die debatte oor 'n lang periode gekom het. Die mens se saligheid en die Verlossingsleer was nietemin, altyd geraak deur die hele proses. In die hele gang van die Vroeë Kerk, met die kompleksiteit van talle kontekste van uitdagings en stryd na binne en na buite, het die Ekumeniese Konsilies inderdaad oorwinning en groeiende bestendiging vir die Apostoliese tradisie gebring (vgl. Labuschagne 2001:971). Die aanvoorwerk van die groot kerkvadere van die begin af het ontsaglike bydraes gelewer. Ons moet, byvoorbeeld, nie uit die oog verloor dat Ignatius van Antiochië (35-107) al vroeg in die kerk se geskiedenis aan ons sy Konfessie (wat neerkom op 'n Regula Fidei), in sy 'Brief aan die Tralliane', voorgehou het (Ignatius 2009d:221), en in sy 'Brief aan die Efesiërs' (2009a) bely Ignatius die Here Jesus as 'God', op hierdie wyse: 'For our God, Jesus Christ, was conceived by Mary according to God's plan, both from the seed of David and of the Holy Spirit' (Ignatius 2009a:197). In sy Regula Fidei bely Irenaeus (ca. 150- pre-200) vir Jesus as 'God' in hierdie woorde:

$[A]$ nd to raise up anew all flesh of the whole human race, in order that to Christ Jesus, our Lord and God and Saviour and King ... 'every knee should bow' ... 'and every tongue confess' to him ... (Young 2007:11)

Tertullianus (ca. 160- post-220) bely in sy Regula Fidei:

there is one only God ... who produced all things out of nothing through his own Word ... that this Word is called his Son, and under the name of God. (Young 2007:10)

En Origenes (ca. 185-254) bely in sy Regula Fidei: 'First, that God is one ... Then again: Christ Jesus ... was made man, was made flesh, although he was God' (Young 2007:10). Wanneer die kerk dan byeenkom in die Eerste Ekumeniese Konsilie van Nicea (325) word Jesus bely as 'God' in die woorde: 'een in wese' (homo-ousios [ópoovolos]) 'met die Vader' (Drobner 2007:293; Young 2007:5). Die Tweede Ekumeniese Konsilie van Konstantinopel (381) brei Nicea uit om groter duidelikheid te bring oor die Godheid van die Heilige Gees. Uiteindelik word die kerk se verstaan van die Triniteit nou tot uitdrukking gebring in die Konfessie van Nicea-Konstantinopel (325 en 381) - na voorafgaande jare van uitgebreide beredenering en ook daaropvolgende jare van verdediging van die kerk se Godsleer en verstaan van Triniteit, rondom die groot teoloë van hierdie periode, soos Athanasius (295-373), die Drie Kappadosiese Vadere (Basilius die Grote [ $\$$ 379], Gregorius van Nyssa [ 1 394] en Gregorius van Nazianzus [ ( ca. 390]), 
en later Augustinus [354-430]). Daarmee het die Triniteit 'n belangrike aspek geword in die verstaan en interpretasie van die Skrif en die Christelike geloof. Van Origenes is die term homo-ousios [een in wese] afkomstig (Lohse 1985:46), en van Tertullianus kom die woorde: una substantia, tres personae [een wese, drie persone], uit sy Teen Praxeas - (Tertullian 2007:598). Soms word die kerk se verstaan van die Godsleer by Nicea-Konstantinopel buite die konteks van die debatte en omstandighede voorgehou as 'n beweging weg van die basiese verstaan van die Nuwe Testament. Lohse (1985) antwoord:

If the development of the doctrine of the Trinity from its beginnings to the end of the fourth century is seen in its totality, it becomes difficult to make such an accusation. In fact, it is more correct to insist upon the opposite, namely, that by means of this dogma the church erected a barrier against the onslaught of the tidal wave of Hellenism, which threatened to inundate the Christian faith ... Neither at Nicaea nor at Constantinople was the attempt made to plumb the depth of the divine mystery or to define God's essence. The intention was, rather, to indicate that God himself encounters us in Jesus Christ, and that in the Holy Spirit God himself is present within his church. (bl. 65-66)

Na die Triniteitsleer het dit vir die kerk nodig geword om ook groter duidelikheid te vind rondom die verstaan van die Christologie. Young beklemtoon: 'Both Trinitarian doctrine and Christology had to be refined in the light of the new Nicene theology' (Young 2007:48).

Die Vierde Ekumeniese Konsilie van Chalcedon (451) het die Christologiese debat tot helderheid gebring. Die Skool van Alexandrië het (onder die invloed van die Monofisiete en die neo-Platonisme) 'n geneigdheid gehad om die eenheid in die persoon van Christus te sterk te beklemtoon. Die Skool van Antiochië het weer die geneigdheid gehad om tweeheid (die menslike en goddelike) in die persoon van Christus te sterk te beklemtoon. Hierdie eensydighede van die skole van Alexandrië en Antiochië (ten opsigte van die menslike en goddelike nature van Christus) is aangespreek by Chalcedon, sodat die eensydighede oorbrug is en die Christologiese debat tot 'n aanvaarde konklusie vir die geheel van die kerk gebring is (vgl. Lohse 1985:93, 94).

Die Ekumeniese Konfessie van Chalcedon bely - na bevestiging van 'the valid creedal statement of the councils of Nicea (325) and Constantinople (381)':

One and the same Christ ... in two natures which undergo no confusion, no change, no division, no separation. (Drobner 2007:487)

Klem is gelê op die eenheid van die persoon van Christus en die individualiteit van die menslike en die goddelike nature (Lohse 1985:93). Hierdie belydenis van die kerk het ingrypende betekenis gehad vir die verstaan van geloof en die beriggewing van die Skrif, in relasie tot die Here Jesus Christus. Van die Vierde Ekumeniese Konsilie van Chalcedon (451) en sy Konfessie sê Young (2007) tereg:

The Council of Chalcedon in 451 produced a christological definition which has remained authoritative for all Western churches, Roman Catholic and Reformed, and for the Orthodox churches of the East. (bl. 77)

In ag genome die Apostoliese tradisie, sê Lohse (1985) van beide die Konfessies van Nicea-Konstantinopel en Chalcedon:

$[I] n$ neither case was any attempt made to unravel the mystery of God. What was attempted was the reformulation and confession of the inherited faith of Christianity vis à vis the questions which had been raised. (bl. 99)

John Macquarrie (2003) hanteer kritiek op die Belydenis van Chalcedon en kom dan tot die volgende konklusie:

The Chalcedonian formula is what the church in a solemn ecumenical council summoned at a critical juncture in its history confessed as the summary of its faith in Jesus Christ. We could hardly reject it without rejecting our identity as Christians. We would not be moving on to a new formulation of Christian doctrine, but moving on to a new religion. (bl. 383)

Oor sy eie teologiese besinning (in sy boek, Jesus Christ in modern thought) sê Macquarrie (2003) dat hy uiteindelik nie wil verskil van die essensie in die tradisionele konfessionele uitsprake van die universele kerk nie:

It is certainly my hope that the Christology set forth in this book, though it does not use the traditional language and categories, stays within the parameters of the Catholic tradition and is entirely compatible with the 'governing intention' of Chalcedon and other classic Christian pronouncements. But to establish this point, we have to look again at the language, and ask whether what has been said in the present exposition says, though in a different way and with different emphases, no less than the church has traditionally said in its confessional statements. (bl. 383)

Macquarrie aanvaar nie Bultmann se afwysing van die tradisionele beskouing van die twee nature van Christus in die Konfessie van Chalcedon nie; Bultmann sien dit as die 'objektivering' van Christus tot 'God-mens', net soos hy die negentiende eeu se liberale standpunt sien as 'objektivering' van Christus tot bloot ' $n$ mens, naamlik 'die historiese Jesus' (Macquarrie 2003:295-296). Macquarrie (2003) vervolg:

I think however that one must judge that Bultmann's fear of 'obectifying' was exaggerated. (bl. 296)

It is no mere doctrine about Christ but sets forth Christ as truly eschatological, that is to say, as one who calls for a fundamental decision about life ... But can such a radical decision be demanded unless one has grounds for believing that the word that comes to us through Jesus is indeed a word from God? This belief cannot rest just on a momentary feeling or on the majority vote of the Christian community. It can rest only on an ontological bond between God and Jesus, and that calls for ontological reflection and probably for historical investigation as well. (bl. 297)

Die interpretasie van die Skrif en die verstaan van die Christelike geloof ondergaan in die tyd van Athanasius, die Kappadosiese Vadere (Basilius die Grote, Gregorius van Nazianzus en Gregorius van Nyssa) en Augustinus verdere verdieping in die lig van die kerk se groter helderheid oor die Triniteit (vgl. Young 2007:53-57). Die begrip perichoresis [onderlinge inwoning/mutual indwelling] - 'n begrip wat 
sedert die 2de helfte van die twintigste eeu weer sterk na vore kom, na die opnuut bewuswording van die belangrikheid van die Triniteit in die teologie van Karl Barth en Karl Rahner, het sy wortels al gehad in die verstaan van die Kappadosiërs en Augustinus.

Berhard Lohse (1985) wys op die volgende belangrike verloop in die teologiese debat - wat inderdaad ons aandag vereis:

During the decades between the death of Origen and the beginning of the Arian controversy, it became clear that the Origenistic doctrine of the Trinity had to be refined in one way or another ... All subsequent theology, however, whether it stands to the 'left' or the 'right' of Origen, owes to him that which is really decisive. For only through him, and since his time, has the task of actually developing a doctrine of the Trinity which progresses beyond the older theologians' 'economic' Trinity and towards an 'immanent' Trinity been recognized, that is to say, a doctrine of the Trinity which sees in the successive revelation of the persons of the divine Trinity at the same time a reference to God's eternal being. (bl. 47-48)

Ekonomiese Triniteit (byvoorbeeld by Irenaeus en Tertullianus) ontwikkel na immanente Triniteit (essensiële Triniteit) by die Kappadosiërs en Augustinus (vgl. Young 2007:37, 55). Die gedagte van onderlinge inwoning (mutual indwelling) by die Kappadosiërs, byvoorbeeld, word deur Young (2007) so saamgevat, in die beskrywing van die Triniteit as:

$[T]$ hey are united in their substance, activities, and will. The whole Trinity is Creator, Saviour, Sanctifier, all three identified with the activities of each and none having a distinct operation of his own. The Whole Trinity is eternal and exists simultaneously and always as Godhead in three hypostases: in other words this is an 'essential Trinitarianism' by contrast with the 'economic Trinitarianism' of Irenaeus and Tertullian. (bl. 54-55)

Die Kappadosiërs neig om die drie persone van die Drieeenheid nietemin soms moontlik te los van die een substansie van God voor te stel (vgl. Young 2007:54). Dit was Augustinus wat baie noukeurig dink in hierdie opsig van die hele verstaan van eenheid en onderlinge inwoning. Sy klassieke uiteensetting vind ons in sy De Trinitate (saamgestel tussen 399 en 419) - (Young 2007:55). Tertullianus se 'Een Substansie in Drie Persone' is deurgaans nog gehandhaaf, maar Augustinus vind dit nodig om tog ook fyner te onderskei, en daarom verkies hy die term 'essentia' bo 'substantia' en die term 'relatio' bo 'persona' (vgl. Young 2007:55-57). Vir Augustinus was veral die woord persona vatbaar vir misverstand, en daarom wil hy tog ook meer dink in terme van relatio [relasie]:

Augustine believed there is a difference between the persons of the Trinity ... What Augustine means here is that the designations 'Father', 'Son', and 'Holy Spirit' do not express either a substantial, or a quantitative, or a qualitative difference, because these do not even exist. What the concept of the persons expresses is, rather, an eternal relation ... The one God, then, is never Father only, or Son only, or Holy Spirit only. He always was, and always will be, the one triune God, namely, Father, Son, and Holy Spirit ... (Lohse 1985:69).
The West has never left out of account this interpretation which Augustine had given to the decisions of the councils of Nicaea and Constantinople. It was he who played the decisive role in warning Latin theology against the danger of tritheism and in keeping it from succumbing to this danger. Appealing to Augustine, Karl Barth rendered the concept of persona by the use of the word 'mode' [Seinsweise] (Lohse 1985:69).

Karl Barth (2008) bring Seinsweise inderdaad in verband met perichoresis [onderlinge inwoning/mutual indwelling]:

The triunity of God obviously implies, then, the unity of Father, Son and Spirit among themselves. God's essence is indeed one, and even the different relations of origin do not entail separations. They rather imply - for where there is difference there is also fellowship - a definite participation of each mode of being in the other modes of being, and indeed, since the modes of being are in fact identical with the relations of origin, a complete participation of each mode of being in the other modes of being. Just as in revelation, according to the biblical witness, the one God may be known only in the Three and the Three only as the one God, so none of the Three may be known without the other Two but each of the Three only with the other Two. (bl. 370)

What is always stated implicitly and explicitly ... is not, of course, the identity of the one mode of being with the others but the co-presence of the others in the one. Since John of Damascus ... this insight has found expression in theology in the doctrine of the perichoresis (circumincessio, passing into one another) of the divine persons. This states that the divine modes of being mutually condition and permeate one another so completely that one is always in the other two and the other two in the one. (Barth 2008:370)

Daarmee word Barth se Trinitariese interpretasie juis verduidelikend ten opsigte van sy verstaan van die Skrif, net soos in die geval van Augustinus. Hoewel breër uitgelê en nader bepaal, word daarmee nogtans nie iets anders gesê nie as dit wat die Apostoliese tradisie in die verlede tot uitdrukking gebring het in hulle Regula Fidei en Konfessies, en waartoe die kerkvadere in teologiese besinning hulle vormende bydraes gelewer het.

Die inagneming van verskillende kontekste, in die interpretasie van tekste, figureer by Augustinus, wanneer hy vier werkswyses aandui: (1) daar moet gepoog word om die bedoeling van 'n skrywer vas te stel. Vir groter duidelikheid word nog drie verdere werkswyses aangedui; (2) daar moet nagegaan word wat duideliker tekste oor dieselfde onderwerp sê; (3) die kerk se tradisionele interpretasie moet nagegaan word; (4) wanneer daar teenstrydende sienings oor 'n teks is, moet die verskillende kontekste van die betrokke gedeelte (met die oog op uitsluitsel) nagegaan word (vgl. Klein, Blomberg \& Hubbard 1993:36-37).

Die Apostoliese tradisie het, in die geheel gesien, 'n blywende en beslissende bydrae gelewer vir die ekumeniese kerk se toekomstige verstaan van geloof en die Skrif. Tog het die Middeleeue 'n dempende invloed gebring vir die goeie voortgang van die Apostoliese tradisie. Dit kan ook as ' $n$ onderbreking en afwyking van hierdie verstaan gesien word. 


\section{Die Middeleeuse Kerk en die verlies van die Apostoliese tradisie: 600-1500}

In 'n toenemende mate het die Middeleeue afgewyk van die Apostoliese tradisie, met die inkorporering van talle afwykende gedagtes wat groterwordende filosofiese akkommodering meegebring het. Die kerk verkeer in hierdie periode egter onder groot kulturele druk van die heersende Grieks-filosofiese intellektuele wêreld. Aanvanklik was die populêre invloed veral gevoed deur die gedagtes van Plato, maar later was dit eerder Aristoteles wat die sterker invloed gehad het. Uiteindelik maak 'n nuwe kerklike tradisie sy verskyning wat die oue wel ingesluit het, maar dit gekompromitteer het met baie nuwe aanpassings wat die menslike posisie, rol en meriete voor God aansienlik verhoog het.

Drie hermeneutiese rigtingwysers is kenmerkend van die Middeleeue (vgl. Labuschagne 2001:973): (1) Die allegoriese verklaringswyse is baie populêr in die Middeleeue; (2) daarteenoor word die voorkeur vir die letterlike interpretasie van die verlede nou opgeneem in wat nou bekend geword het as die Middeleeuse skolastiek. Die skolastiek wou met gebruikmaking van die Aristoteliese logika 'n meer rasionele begronding aanbied vir die letterlike verstaan van die Skrif. In hierdie verband kan verwys word na Anselmus (1033-1109), Abelardus (1079-1142), en veral Thomas van Aquinas (1225-1274); (3) 'n mate van handhawing van die kerklike tradisie van die verlede, wanneer wel verwys is na die verstaan van kerkvaders soos byvoorbeeld Augustinus (354-430) en Hieronymus (ca. 342-420).

'n Proposisionele waarheidsbeskouing maak sy verskyning in die Middeleeue, wanneer die waarheid op verbasende wyse objektiveer word in die leerstellings en dogmas van die kerk. Die uitdrukking van die lewende geloof van die Apostoliese tradisie het vervaag. Lohse (1985) wys onder andere op die volgende:

It was not until the Middle Ages that the Catholic church developed the doctrine of the depositum fidei, i.e., the conception that the church had been entrusted with a certain treasure of truths, none of which was to be lost; yet the treasure was capable of further development in the sense of a more explicit ramification of these truths. The full consequence of this conception was that modern Catholicism has claimed infallibility for its dogmas, as it did at the Council of Trent and at the First Vatican Council. The understanding of dogma as a revealed proposition of faith was thus by no means characteristic of the ancient church. (bl. 7-8)

In die Middeleeue het die Vroeë Kerk se apostoliese suksessie ook verword, met nou 'n verskuiwing weg van die oorspronklike oordrag van die waarheid wat van die apostels ontvang is, na die oordrag van menslike posisies, mag en aansien (vgl. Van de Beek 2012:262).

Wat betref die Triniteit en die Christologie redeneer Thomas Aquinas nog essensieel op die basis van Augustinus en die definisie van Chalcedon (Walker 1968:246). Nogtans moet onthou word dat Thomas Aquinas enersyds werk met die Triniteit in terme van God se openbaring, en aan die ander kant tog ook werk met die filosofie en dan aanspraak maak op kennis van God vanuit die vermoëns van die reflektiewe menslike rede (Copleston 1957:52). Froehlich (1998:88) sê met reg van Thomas Aquinas se hermeneutiese benadering in Thomas se Summa Theologiae: 'Thomas still trusted words. Human language about God, though never adequate to encompass its subject, does speak the truth analogically'. Aquinas se siening oor analogia entis [analogie van die syn/analogy of being] veronderstel dat God alles op ' $n$ bepaalde wyse geskep het sodat daar op een of ander wyse 'n analogie bestaan tussen God en die wêreld wat deur God geskep is. En hiervolgens is dit moontlik vir die menslike bewussyn om analogies (in terme van 'n korrespondensie) tog afleidings te kan maak en te praat oor God vanuit bekende objekte en verhoudinge van hierdie deur God geskape wêreld (vgl. McGrath 2005:253-255). Vir Karl Barth kan ons spreke oor God nooit sy laaste grond vind in die menslike bewussyn nie - en dit geld nie slegs van Aquinas se analogia entis nie, maar ook van die Liberale Teologie van die negentiende en twintigste eeu. Analogia relationis is Barth se alternatief vir Aquinas se analogia entis:

In questioning the analogia entis, Barth is attempting to preserve both the 'indirectness' and the openness of revelation, to keep God from being the immanent possibility of human reason or religious affections. With the analogia relationis, Barth is attempting to preserve the transcendent freedom of God, and the importance of revelation for right knowledge of God. He is attempting to uphold sola gratia, to avoid Catholic synergism (with regard to salvation that places a strong emphasis on human works) on the one hand, and liberal immanentism on the other. (Price 2002:133)

Aquinas het in sy vermenging van teologie en filosofie uiteindelik ruimte gevind vir die twee dominerende Middeleeuse oortuigings van God se genade en menslike meriete (Walker 1968:247).

\section{Slot}

Vanuit hierdie studie kan daar met reg gesê word dat die Apostoliese tradisie deurgaans 'n sentrale posisie inneem in die Vroeë Kerk se behoud van eenheid en goeie voortgang. Die Ekumeniese Konfessies van hierdie periode is uitdrukking van die geloof van die Vroeë Kerk en die Apostoliese tradisie. Die samebindende waarde van die Apostoliese tradisie, vir die eenheid van die Apostoliese Kerk, word ook verder baie duidelik wanneer die Westerse kerk die fout maak om, sonder om die kerk van die Ooste na behore daarin te ken in 'n Ekumeniese Konsilie, gaandeweg en eensydig die 'filioque'-klousule in te voeg in die Niceense Geloofsbelydenis. Die eenheid van die Apostoliese Kerk het uitdruklik daarmee in die gedrang gekom. Dit het vervolgens grootliks bygedra tot die skeuring van die Westerse en die Oosterse kerk in 1054 (vgl. Letham 2009:45-49).

Wanneer ons vandag terugskouend nadink in terme van geloofseenheid en die behoud van die eenheid van die 
kerk oor die wêreld en deur die eeue, word in groeiende mate op die ekumeniese terrein besef en raakgesien dat die Apostoliese tradisie in hierdie soort nadenke en ekumeniese gesprek 'n sentrale posisie inneem (vgl. Gross 2000:280-291). Dit word meer en meer duidelik dat daar eintlik op geen ander wyse oor die kerk se verstaan van haarself, haar geloof en haar verstaan van die Skrif, vordering gemaak sal word nie. Die studie van die Vroeë Kerk en die Apostoliese tradisie het opnuut weer baie belangrik geword vir juis vandag se verstaan van ons geloof:

The creedal statement known as the Nicene-Constantinopolitan $\ldots$ is undoubtedly the best witness to the unity of the churches in the apostolic faith ... It reminds all Christians and all communities of their faith, and links it with the faith of all ages and all places. (Confessing the One Faith 2010:xiii)

Hierdie slotsom word ook bevestig in 'n studie van 2015, 'Die Apostoliese tradisie in die Kerk se verstaan van Skrif en geloof vanaf Reformasie tot aan die begin van die 21ste eeu 'n Kort hermeneutiese oorsig (vgl. Labuschagne ter perse]).

\section{Erkenning \\ Mededingende belange}

Die outeur verklaar dat hy geen finansiële of persoonlike verhouding(s) het wat hom op 'n voordelige of nadelige wyse in die skryf van die artikel beïnvloed het nie.

\section{Literatuurverwysings}

Barnett, P., 1998, Historische zoektocht naar Jezus, transl. H. Lalleman-de Winkel \& P.J. Lalleman, Uitgeverij Boekencentrum, Zoetermeer.

Barth, K., 1955, Die Kirchliche Dogmatik, IV, 2, Die Lehre von der Versöhnung, Evangelischer Verlag, Zürich.

Barth, K., 2000, Church dogmatics, IV, 2, The doctrine of reconciliation, transl. G.W. Bromiley, T\&T Clark, Edinburgh.

Barth, K., 2008, Church dogmatics, I, 1, The doctrine of the word of God, transl. G.W. Bromiley, T\&T Clark, London.

Caputo, J.D., 1987, Radical Hermeneutics - Repetition, deconstruction, and the hermeneutic Project, Indiana University Press, Bloomington and Indianapolis, IN.

Confessing the One Faith, 2010, An ecumenical explication of the apostolic faith - As it is confessed in the nicene-constantinopolitan creed (381) rev. edn., World Council of Churches Publication, Geneva. (Faith and Order Paper, 153).

Copleston, F.C., 1957, Aquinas, Penguin Books, Harmondsworth.

Drobner, H.R., 2007, The fathers of the church - A comprehensive introduction, transl. S.S. Schatzmann, Hendrickson Publishers, Peabody, MA.

Froehlich, K., 1998, s.v. 'Thomas Aquinas', in D.K. McKim (ed.), Historical Handbook of major biblical interpreters, pp. 85-91, InterVarsity Press, Leicester.

Gadamer, H-G., 2006, Truth and method, transl. J. Weinsheimer \& D.G. Marshall, Continuum, London.
Gross, J. (ed.), 2000, Growth in Agreement II, World Council of Churches Publications, Geneva.

Ignatius, 2009a, 'To the Ephesians', in M.W. Holmes (ed.), The Apostolic Fathers, pp. 182-201, Baker Academic, Grand Rapids, MI.

Ignatius, 2009b, 'To the Magnesians', in M.W. Holmes (ed.), The Apostolic Fathers, pp. 202-213, Baker Academic, Grand Rapids, MI.

Ignatius, 2009c, 'To the Smyrnaeans', in M.W. Holmes (ed.), The Apostolic Fathers, pp. 248-261, Baker Academic, Grand Rapids, MI.

Ignatius, 2009d, 'To the Trallians', in M.W. Holmes (ed.), The Apostolic Fathers, pp. 214-223, Baker Academic, Grand Rapids, MI.

Irenaeus, 2010, 'Against Heresies (Book III)', in A. Roberts, J. Donaldson \& A. Cleveland Coxe (eds.), Saint Irenaeus of Lyons - Against Heresies, pp. 275-391, Ex Fontibus, n.p.

Klein, W.W., Blomberg, C.L., Hubbard, R.L. (jnr.), (eds.), 1993, Introduction to Biblical interpretation, Word Publishing, Dallas, TX.

Labuschagne, J.P. (Kobus), 2001, 'Geloofsekerheid in die kerk se geskiedenis van Bybelinterpretasie', HTS Teologiese Studies/Theological Studies 57(3/4), 959-988. $\mathrm{http}: / / \mathrm{dx}$.doi.org/10.4102/hts.v57i3/4.1859

Labuschagne, J.P. (Kobus), 2013, 'A hermeneutical reflection on the resurrection of Jesus Christ in question and answer 45 of the Heidelberg Catechism', In die Skriflig/In Luce Verbi 47(2), Art. \#709, 10 pages. http://dx.doi.org/10.4102/ids. v47i2.709

Labuschagne, J.P., (ter perse), 'Die Apostoliese tradisie in die Kerk se verstaan van Skrif en geloof vanaf Reformasie tot aan die begin van die 21ste eeu - 'n Kort hermeneutiese oorsig', HTS Teologiese Studies/Theological Studies 71(3).

Letham, R., 2009, 'The Trinity between East and West', Journal of Reformed Theology 3, 42-56. http://dx.doi.org/10.1163/156973109X403714

The Letter of the Church of God at Smyrna to the Church of God at Philomelium, 2009, 'The Martyrdom of Polycarp', in M.W. Holmes (ed.), The Apostolic Fathers, pp. 298-333, Baker Academic, Grand Rapids, MI.

Lohse, B., 1985, A short history of Christian doctrine, transl. F.E. Stoeffler, Fortress Press, Philadelphia, PA.

Macquarrie, J., 2003, Jesus Christ in modern thought, SCM Press, London.

McGrath, A.E., 2005, Christian theology: An introduction, Blackwell Publishing, Oxford.

Moltmann, J., 2000, Experiences in theology: Ways and forms of Christian Theology, transl. M. Kohl, Fortress Press, Minneapolis, MN.

Moltmann, J., 2010, Sun of righteousness, ARISE! God's future for humanity and the earth, transl. M. Kohl, Fortress Press, Minneapolis, MN.

Price, D.J., 2002, Karl Barth's anthropology in light of modern thought, William B. Eerdmans, Cambridge.

Ricoeur, P., 2009, Hermeneutics and the human sciences, transl. J.B. Thompson (ed.), Cambridge University Press, Cambridge.

Schwöbel, C., 2009, 'The Trinity between Athens and Jerusalem', Journal of Reformed Theology 3, 22-41. http://dx.doi.org/10.1163/156973109X403705

Tertullian, 2007, 'Against Praxeas', in A. Roberts, J. Donaldson \& A. Cleveland Coxe (eds.), The Ante-Nicene Fathers, vol. 3, pp. 597-632, Cosimo Classics, New York, NY.

Van de Beek, A., 2012, Lichaam en Geest van Christus - De theologie van de kerk en de Heilige Geest, Uitgeverij Meinema, Zoetermeer.

Walker, W., 1968, A History of the Christian Church, rev. edn., T. \& T. Clark, Edinburgh.

Young, F.M., 2002, Biblical exegesis and the formation of Christian culture, Hendrickson Publishers, Peabody, MA.

Young, F.M., 2007, The making of the creeds, SCM Press, London.

Young, F.M., 2010a, 'Being Holy in the cities of the Roman Empire', in F. Young \& M. Hooker (eds.), Holiness and mission: Learning from the Early Church about mission in the city, pp. 37-62, SCM Press, London.

Young, F.M., 2010b, 'The challenge of establishment - Did a Christian Empire help or hinder?', in F. Young \& M. Hooker (eds.), Holiness and mission: Learning from the Early Church about mission in the city, pp. 63-86, SCM Press, London. 